\title{
Effect of Synectic Model on Achievement Moti- vation in Relation to Its Cognitive Style Among SECONDARY SCHOOL STUdENTS
}

\author{
Gagnita Chahal (iD and Kanwalpreet Kaur (D)
}

The Synectic method assists in achieving goals in the English language by incorporating reflective and imaginative tools rendering the teaching-learning process more interactive and breaking the monotonous routine of a classroom. Achievement motivation typically refers to the level of one's motivation to engage in achievement behaviour. The study examines the effect of the Synectic model on achievement motivation with its cognitive styles among secondary school students. The sample for the investigation comprised 100 students of class IX English medium private schools of Patiala affiliated to CBSE within the age ranges of 13-15 years. The results show that the mean gain achievement motivation of the group taught by the Synectic model was significantly higher than the group taught through the conventional method. The mean gain achievement motivation of the field-independent cognitive style group was also significantly higher than the field-dependent cognitive style group. The interaction effect of the different instructional strategies with different cognitive styles in respect of gain achievement scores on achievement motivation was also significant.

KEYWORDS: Synectic Model, Achievement Motivation, Field Independent, Field Dependent

\section{INTRODUCTION}

Education is believed to be a determinant of the progress and prosperity of a nation. The development is the result of explosion of knowledge and innovations in every sector of the society. All such innovations are directly or indirectly related to human ingenuity and creative potentialities. Invention

Gagnita Chahal $\square$

Department of Education, Panjab University, Chandigarh, India.

Email: gagnita499@gmail.com. ORCID: https://orcid.org/0000-0003-2034-6474

Kanwalpreet Kaur

Institute of Educational Technology and Vocational Education, Panjab University, Chandigarh, India.

Email: sherrysidhu1221@gmail.com. ORCID: https://orcid.org/0000-0001-9640-9086 
and creativity are vital for the progress of society and plays a role in making life more meaningful. One of the central human resources of all innovation educational endeavour is learner. But it is also true that in our country high percentage of school going children are experiencing perceptual, cultural, and emotional blocks. The environment available in the home and school is not conducive to free inquiry and divergent production. To prepare students to anticipate future demands and achieve educational goals in all educational settings, it is important for the teachers and teacher educators to develop skills in all the cognitive domains. (Ferrari \& Cachia, 2009).

One of the major aims of education is to make students successful social beings; therefore, efforts should be made to provide social practices along with formal education. Here, Synectic Method assists in achieving goals in English language by incorporating reflective and imaginative tools rendering the teaching learning process more interactive and breaks the monotonous routine of normal classroom setting. The students are free to develop imagination and insight into their everyday activities. Synectic's fully supports content instruction. The students learn on their own with the help of fun based and self-performed activities which stimulates their hidden creative and original ideas. English being the medium of instruction in private schools based on CBSE board, lays strong emphasis on learning of different skills- Listening, Speaking, Reading and Writing which can be enhanced through uplifting their level of achievement motivation.

Achievement motivation is the drive to work with diligence and vitality, to constantly steer toward targets, to obtain dominance in challenging and difficult tasks and create sense of achievement as a result (Biegge \& Hunt, 1980). Achievement is task-oriented behaviour that allows the individual's performance to be evaluated according to some internally or externally imposed criterion that involves the individual in competing with others; or that otherwise involves some standard of excellence. The interaction of achievement, expectancy of success and the incentive value of success are the parameters needed for it. Students' motivation towards English, has been decreased after they get enrolled in school, thus, enhancing the motivation of students with different learning styles has become a very important area to the researcher.

The theory of achievement motivation is a miniature system applied to a specific context, the domain of achievement-oriented activities, which is characterized by the fact that the individual is responsible for the outcome (success or failure), one anticipates unambiguous knowledge of results, and there is some degree of uncertainty or risk. Yet it is our belief that the type of theory that views the strength of an individual's goal-directed tendency as jointly determined by his motives, by his expectations about the consequences of his actions and by the incentive values of expected consequences will have 
wider utility when these concepts are applied toward other goals (Atkinson \& Feather, 1966). The Synectic model based teaching provides opportunities for students to explore and construct meaningful knowledge. It also can build up students' abilities to learn English beyond school. Thus, it is very important to investigate how senior secondary students with different learning styles have their motivation affected by the Synectic model teaching.

The term "cognitive" is a comprehensive term covering the various standards of knowing, perceiving, anticipating, imagining, remembering, conceiving, judging, reasoning, understanding, reflecting and problem solving. Cognitive area is primarily concerned with intellectual growth of the individual. A person's cognitive style is determined by the way in which a person responds to the environment in which he is enrooted. The most vastly studied cognitive styles are field-independence and field-dependence. At perceptual level, field independent personalities can distinguish figures as discrete from the backgrounds compared to field dependent individual who experience events in an undifferentiated way. Both field dependent and field independent learners have distinctive strengths in learning. Field dependent learners are superior in social skills, whereas field independent learners are superior in cognitive restructuring skills. Messick (1995) described cognitive style as a distinctive fashion of perceiving, remembering, thinking and problem-solving, reflective of information processing regularities that develop in agreeable ways around underlying personality trends. It is inferred from consistent individual differences in ways of organizing and processing information and experience. Liu and Ginther (1999) referred cognitive styles to the individual's consistent and characteristic tendency of perceiving, remembering, organizing, processing, thinking a problem solving.

In this study, the researcher has employed this cognitive style to classify the students based on field-dependence and field independence. Therefore, the present research was planned to study the achievement motivation of secondary school students of Patiala district keeping in consideration their cognitive style using the Synectic Model.

\section{Review o F Literature}

Kaur (2015) explored the relationship between achievement motivation and different styles of learning among university students. The findings revealed that there was no significant relationship between the reproducing dimension of learning style and achievement motivation of university students, whereas there was significant relationship between the constructive dimension of learning style and achievement motivation among university students.

Yaman, Dundar, and Ayvaz (2017) carried out research which aimed 
to reveal whether there was a relation between achievement motivation of teacher candidates according to their cognitive styles and motivation styles. This quantitative study used both comparative and correlational survey methods because it was aimed to determine cognitive styles, motivation styles and achievement motivation of the teacher candidates and to investigate the relationship between these variables. Findings revealed that achievement motivation of the teacher candidates did not differ significantly in terms of gender and cognitive styles. However, it was found that achievement motivation of the teacher candidates differed significantly in terms of their grade levels and motivation styles.

Kamaluddin and Kade (2017) studied the impact of Synectic Learning Model with Mind Mapping Assignment in Improving Student's Learning Outcomes and Cognitive Ability at Lab School Junior High School Palu. The percentage of the initial test mean score (pre-test) for students' cognitive abilities before learning process (pre-test) were 21, 78\% from the ideal score, and then increased until $71,68 \%$ after cognitive learning process with post-test. The significance of the percentage increase in the mean score of pre-test and post-test could be represented by gains normalized mean score for the cognitive achievement of students at $63.43 \%$ which could be categorized as a high result. These results showed that the students' cognitive abilities were high. The obtained results indicated that the application of Synectic learning model with mind mapping assignment could increase cognitive abilities.

Pooja (2018) probed to see the effect of multimedia instruction on academic achievement in relation to cognitive styles and achievement motivation of $9^{\text {th }}$ grade students in English. The findings revealed that the field independent students having high achievement motivation had significantly higher academic achievement than the field independent students having low achievement motivation. Students with high achievement motivation taught through multimedia instruction had significantly higher academic achievement than the students with high achievement motivation taught through traditional instruction and there existed no significant difference in academic achievement of students with field independent cognitive style having low achievement motivation and students with field dependent cognitive style having high achievement motivation.

Sujito, Budiharso, Solikhah, and Mutaqin (2020) examined the effects of applying two different forms of analogy, namely written and oral analogy, while also considering learners' cognitive styles, on students learning outcomes for a research course in English as a Foreign Language. The results showed that subjects given oral analogy achieved better learning outcomes than those who received written analogy. In addition, subjects with the field-independent cognitive style exhibited greater learning achievement 
that those with the neutral and field-dependent cognitive styles. There was no significant interaction between the different analogy types and subjects' cognitive styles in the results of the research course.

Ernita, Muin, Verawati, and Prayogi (2021) explored the effect of the inquiry learning model based on laboratory and achievement motivation toward students' physics learning outcomes. The research sample was 2 class groups in one high school in the city of Mataram. The first experimental group used inquiry learning model based on real laboratory and the second experimental group used inquiry learning model based on virtual laboratory. The questionnaire of achievement motivation scale was used to measure the students' achievement motivation, and a test was used to measure students' learning outcomes focusing on cognitive aspects. The research results showed that; a) there is no significant difference between the students' learning outcomes who learn using the inquiry learning model based real laboratory and virtual laboratory; b) there is no significant difference between the students' learning outcomes who have the high achievement motivation and low achievement motivation; and c) there is no interaction between inquiry learning model based real laboratory and virtual laboratory with the achievement motivation (high and low) on the students' learning outcomes.

The studies reviewed above revealed that students taught with the help of analogies showed a considerable difference in their learning outcomes. The subjects with field-independent cognitive styles exhibited greater learning achievement than those with the field- dependent cognitive styles. Fewer studies showed that there existed no significant difference in academic achievement of students with field independent cognitive style having low achievement motivation and students with field dependent cognitive style having high achievement motivation.

\section{Objectives of the Study}

The objectives of the study are:

1. To study the effect of two instructional treatments on achievement motivation scores with respect to cognitive styles.

2. To study the effect of two instructional treatments on achievement motivation for field independent and field dependent group of students.

\section{HyPothesES OF THE STUdY}

The study has the following hypotheses:

1. The two instructional treatments will yield no comparable mean gain on 
achievement motivation.

2. The field-independent and field-dependent group of students will yield no comparable mean gain scores on achievement motivation.

3. There will be no significant interaction effect of instructional treatments and cognitive styles on achievement motivation.

\section{Research Design}

The study was conducted on two intact groups i.e., experimental and control groups. Subjects of the sample were not chosen randomly so quasi- experimental design was used. These two different groups were designated as experimental group and control group. Out of these two groups, the experimental group was taught through the Synectic Model teaching strategy and the control group was taught through conventional teaching approach. $2 \times 2$ factorial design was employed in which mean gain scores on achievement motivation and categories of cognitive styles viz. field-dependent and field-independent will be studied. The following instruments were used for the present study:

1. Group Embedded Figures Test (GEFT) by Witkin, Oltman, Raskin, and Karp (1971).

2. Achievement Motivation Scale by Deo and Mohan (2011).

\section{SAMPLE OF THE StUdy}

The sample for the investigation comprises 100 students of class IX English medium private schools of Patiala affiliated to CBSE within the age ranges of 13-15 years. The results interpreted in the study are based on a sample of 100 students with 50 students in experimental group and 50 students in control group. These students were exposed to two instructional strategies out of which 25 were field-independent and 25 field-dependent in each group.

\section{Research Procedure}

After taking the permission from heads of the concerned schools, the participants were approached. The intact sections were randomly selected out of two schools. Students were selected purposively based on their cognitive styles to be analysed using Group Embedded Figures Test (GEFT) by Witkin et al. (1971). The students were divided into two groups viz. Field-dependent and Field-independent. The students were then randomly assigned to experimental and control groups for investigating their achievement motivation for experimental treatment. Thus, all the groups had 25 students each. 


\section{Results AND Discussion}

Analysis and Interpretation of data for determining the gain achievement motivation test scores, ANOVA was computed to evaluate the main effects and interaction of variable of instructional strategies (Synectic Model and Conventional Approach) in relation to its Cognitive styles (Field Independent and Field Dependent).

\section{Pre-Test Comparison of Experimental and Control Group on Achieve- ment Motivation On the basis of Instructional Strategies}

The mean scores of achievement motivation for experimental and control group have been given in the Table 1. Pre-achievement motivation test was administered to check the achievement motivation on experimental and control group separately, before the experimental treatment. The preachievement-motivation test helped in analysing the effect of instructional strategies by comparing the students with post-achievement motivation test.

Table 1

Pre-Test Comparison of Experimental and Control Group on Achievement Motivation.

\begin{tabular}{llcccc}
\hline Variable & Groups & N & Mean & SD & \multirow{2}{*}{} \\
\hline Achievement & Experimental Group & 50 & 138.44 & 16.10 & \multirow{2}{*}{0.61} \\
Motivation & Control Group & 50 & 136.70 & 12.02 & \\
\hline
\end{tabular}

It is evident from Table 1 that the pre-mean scores of achievement motivation of the experimental group were 138.44 and of control group was 136.70 respectively. The values of SD of experimental group and control group were 16.10 and 12.02 respectively. It is further indicated that the obtained $t$ value of achievement motivation test score is 0.61 . The $t$ value is less than the table value (1.98) at 0.05 level of significance. Therefore, there is no significant difference in achievement motivation of experimental and control groups of students before treatment. Hence, both the groups were found to be almost equal as far as their previous achievement motivation on the basis of instructional strategy is concerned.

\section{Pre-Test Comparison of Experimental and Control Group on Achieve- ment Motivation on the Basis of Cognitive Style}

This section compares the achievement motivation scores in relation its cognitive style i.e., field-independent and field-dependent groups of IX class stu- 
dents before experimental treatment as shown in Table 2.

\section{Table 2}

Pre-Test Comparison of Field Independent and Field Dependent of Experimental and Control Group on Achievement Motivation.

\begin{tabular}{lllllll}
\hline Variable & $\begin{array}{l}\text { Cognitive } \\
\text { Style }\end{array}$ & Groups & N & Mean & SD & $t$ \\
\hline \multirow{4}{*}{$\begin{array}{l}\text { Achievement } \\
\text { Motivation }\end{array}$} & Field & Experimental & 25 & 145.64 & 13.32 & 0.61 \\
& & Group & & & & \\
& Field & Control Group & 25 & 143.48 & 11.43 & \\
& Dependent & Group & 25 & 131.24 & 15.61 & 0.37 \\
& & Control Group & 25 & 129.92 & 8.27 & \\
\hline
\end{tabular}

It is evident from the Table 2 that the mean score of achievement motivation having field independent type of cognitive style before experimental treatment of the experimental group was 145.64 and of control group was 143.48 respectively. The values of SD of field independent type of cognitive style of experimental group and control were 13.32 and 11.43 respectively. It is further indicated that the mean score of achievement motivation having field dependent type of cognitive style before experimental treatment of the experimental group and control group were 131.24 and 129.92 respectively. The values of SD of field dependent type of cognitive style of experimental group and control group were 15.61 and 8.27 . The obtained $t$ values testing the significance of mean difference on achievement motivation on the basis of cognitive style are 0.61 and 0.37 of both the groups which in comparison to the table value was found to be not significant at 0.05 level of significance. Hence, it is indicating that, there exists no significance difference in achievement motivation of field independent and field dependent groups of students.

\section{Analysis of Mean Gain Scores of Different Cognitive Styles on Achieve- ment Motivation Test}

Table 3 shows the mean gain scores of different sub-groups of cognitive styles on achievement motivation for experimental and control groups.

From Table 3, it can be observed that mean gain scores on achievement motivation having field independent cognitive style of experimental group were 19.68 and of control group were 9.08. This indicated that the mean gain score of field independent cognitive style on achievement motivation is higher 
301 | Gagnita Chahal and Kanwalpreet Kaur

Table 3

Mean and SD of Gain Scores of Different Cognitive Styles on Achievement Motivation of Experimental and Control Groups.

\begin{tabular}{llcccccc}
\hline \multirow{2}{*}{$\begin{array}{l}\text { Dependent } \\
\text { Variable }\end{array}$} & Cognitive Styles & \multicolumn{3}{c}{$\begin{array}{c}\text { Experimental } \\
\text { Group }\end{array}$} & \multicolumn{3}{c}{ Control Group } \\
\cline { 3 - 8 } & & $\mathbf{N}$ & Mean & SD & N & Mean & SD \\
\hline $\begin{array}{l}\text { Achievement } \\
\text { Motivation }\end{array}$ & Field & 25 & 19.68 & 8.53 & 25 & 9.08 & 3.63 \\
& $\begin{array}{l}\text { Independent } \\
\text { Field Dependent }\end{array}$ & 25 & 9.56 & 4.12 & 25 & 3.84 & 2.12 \\
\hline
\end{tabular}

for the experimental group than the control group. Further, for field dependent cognitive style, it was observed that the mean gain scores on achievement motivation having field dependent cognitive style of experimental group were 9.56 and of control group were 3.84. This shows that the mean gain score of field dependent cognitive style on achievement motivation was higher for the experimental group than the control group.

Further, from Table 3 it can be seen that the standard deviation of field independent cognitive style on achievement motivation of the group imparted instruction through Synectic model was 8.53 and of control group was 9.08 taught through conventional mode of instruction. The standard deviation of field dependent cognitive style on achievement motivation of the group imparted instruction through Synectic model was 4.12 and of control group was 3.84, taught through Conventional mode of instructions.

\section{Analysis of Variance of Gain Scores on Achievement Motivation In rela- tion to their Instruction Strategy and Cognitive Style}

The mean of different sub-groups, sum of squares, degree of freedom, mean sum of squares and F-ratio have been presented in Table 4.

\section{Main Effect}

\section{Instructional Strategy}

It may be seen from the Table 4 that the F-ratio for difference in the mean gain scores on achievement motivation for group taught with Synectic Model and Conventional method of teaching is 61.96, which in comparison to the table value was found to be significant at 0.01 level of significance. It reveals that there is a significant difference in the mean gain scores of achievement motivation of secondary school students when taught with Synectic Model (experimental group) than Conventional method of teaching (control group). 
Table 4

Summary of Analysis of Variance (2x2) Factorial Design.

\begin{tabular}{llcccc}
\hline $\begin{array}{l}\text { Dependent } \\
\text { Variable }\end{array}$ & Source of Variation & $\begin{array}{c}\text { Sum of } \\
\text { Squares }\end{array}$ & df & $\begin{array}{c}\text { Mean } \\
\text { Squares }\end{array}$ & $\boldsymbol{F}$ \\
\hline \multirow{2}{*}{$\begin{array}{l}\text { Achievement } \\
\text { Motivation }\end{array}$} & Instructional Strategy & 1664.640 & 1 & 1664.64 & $61.96^{* *}$ \\
& Cognitive Style & 1474.560 & 1 & 1474.56 & $54.89^{* *}$ \\
& $\begin{array}{l}\text { Instructional Strategy } \\
\text { x Cognitive Style }\end{array}$ & 148.840 & 1 & 148.84 & $5.54^{*}$ \\
& Between & 2578.800 & 96 & 26.86 & \\
\hline
\end{tabular}

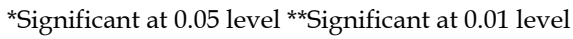

It may, thus, be concluded that the use of different instructional strategies to impart instruction in English attributed to development of difference in mean gain scores of achievement motivation. The hypotheses $\mathrm{H}_{1}$ viz., "The two instructional treatments will yield no comparable mean gain on achievement motivation" was rejected as the students of experimental group, learnt lessons of English by Synectic Model, exhibited better level of achievement motivation as compared to the students of control group who learnt by Conventional method of teaching. This finding is in accordance with the research findings of Rahmawat (2018) investigated a significant difference in reading comprehension between students with high achievement motivation who taught by using CIRC strategy and those taught with the conventional strategy and further, there was significant difference in reading comprehension between the students with low achievement motivation who taught by using CIRC strategy and those taught with the conventional strategy.

\section{Cognitive Style}

It may be seen from Table 4 that the F-ratio for difference in the mean gain scores on achievement motivation for different cognitive style i.e., field independent and field dependent for both the groups taught with Synectic Model and Conventional method of teaching is 54.89, which in comparison to the table value was found to be significant at 0.01 level of significance. This reveals that there is a significant difference in the mean gain scores of achievement motivation scores of secondary school students in relation to its different cognitive style. It may, thus, be concluded that the use of different cognitive style attributed to the development of difference in mean gain scores of achievement motivation. The hypotheses $\mathrm{H}_{2}$ viz., "The field dependent and field independent group of students will yield no comparable mean gain scores on achievement motivation" was rejected as field independent students had 
better level of achievement motivation than the field dependent students. Similar results were obtained by Sharma and Ranjan (2018) observed a significant effect of cognitive style and achievement motivation on academic achievement was significant.

\section{Interaction between Instructional Strategy and Cognitive Style on Achieve- ment Motivation}

It may be observed from Table 4 that F-ratio for interaction between instructional strategy and cognitive style on achievement motivation is 5.541, which in comparison to the table value was found to be significant at 0.01 level of significance. The result indicates that there was a significant difference in the gain scores on achievement motivation due to interaction effect of instructional strategies and cognitive styles. The hypotheses $\mathrm{H}_{3}$ viz., "There will be no significant interaction effect of instructional treatments and cognitive styles on achievement motivation" was rejected as the students with field independent and field dependent cognitive style taught with different instruction treatment attributed to the difference in mean gain scores of achievement motivation. The results of the present finding were in accordance with the research findings of Buchori et al. (2017) who revealed a significant interaction between learning strategies and achievement motivation towards cognitive learning outcomes.

The results of the study can be summarised as:

1. The Synectic Model is found to be significantly more effective and fruitful in teaching English as compared to conventional method of teaching.

2. The mean gain achievement motivation of the group taught through the Synectic Model was found to be significantly higher than the group taught through conventional method of teaching.

3. The mean gain achievement motivation of field-independent cognitive style group was found to be significantly higher than the field-dependent cognitive style group.

4. The interaction effect of the different instructional strategies with different cognitive styles in respect of gain achievement scores on achievement motivation was found to be significant.

\section{Conclusions of THE STUdy}

Synectic's is a useful tool in creative problem solving and enhancement of academic performance along with writing creativity to a greater extent. It has shown itself to be an effective approach for improving students learning in concept formation, skill development and content area knowledge. It evoked interest in students and helped in better retention of vocabularies and addition 
of new words overtime. The model permitted them to form deeper connection with the concepts learnt and this activity transformed abstract concepts into concrete. It was found that when abstract concepts were taught using analogies, students were able to redefine the concepts using their own words, relate concepts to their daily life and apply the concepts in their day to day lives. The students taught through Synectic model showed higher achievement motivation than the ones taught with conventional teaching strategy. The students should be taught with various new strategies in order to improve their motivation to achieve or gain in a subject area and in day-to-day existence as well.

The schools should organize different curricular and co-curricular activities and should promote students. It is not only the responsibility of the school and teachers to promote achievement motivation but also the home, parents, elders, neighbours must share its contribution. It is recommended that the teacher and the parents should set high goals before the students. It helps the students to achieve high level of aspiration. It is suggested that teachers can help the students to equip with necessary skills and competencies to enhance student's achievement motivation.

\section{REFERENCES}

Atkinson, J. W., \& Feather, N. T. (1966). A theory of achievement motivation. New York: John Wiley \& Sons.

Biegge, M. O., \& Hunt, Y. B. (1980). Intrapersonal and interpersonal theories of motivation from an attributional perspective. Educational Psychology Review, 12(1), 1-14.

Buchori, A., Setyosari, P., Dasna, I. W., Ulfa, S., Degeng, I. N. S., \& Sadijah, C. (2017). Effectiveness of direct instruction learning strategy assisted by mobile augmented reality and achievement motivation on students cognitive learning results. Asian Social Science, 13(9), 137-144.

Deo, P., \& Mohan, A. (2011). Manual: Achievement motivation scale (and others, Ed.). Agra: National Psychological corporation.

Ernita, N., Muin, A., Verawati, N. N. S. P., \& Prayogi, S. (2021). The effect of inquiry learning model based on laboratory and achievement motivation toward students' physics learning outcomes. Journal of Physics: Conference series, 1816. Retrieved from https://iopscience .iop.org/article/10.1088/1742-6596/1816/1/012090/meta

Ferrari, A., \& Cachia, R. (2009). Innovation and creativity in education and training in the EU member states: Fostering creative learning and supporting innovative teaching literature review on innovation and creativity in EET in the EU member states (ICEAC). Retrieved 2021-03-14, from 
https://www.researchgate.net/publication/265996963

Kamaluddin, D., \& Kade, A. (2017). Impact of synectic learning model with mind mapping assignment in improving student's learning outcomes and cognitive ability at lab school junior high school Palu. In First indonesian communication forum of teacher training and education faculty leaders international conference on education 2017 (Vol. 174). Atlantis Press. Retrieved from https://www.atlantis-press.com/ proceedings/ice-17

Kaur, J. (2015). A study of achievement motivation of university students in relation to their learning styles. International Journal of Humanities and Social Science Research, 1(1), 52-54.

Liu, Y., \& Ginther, D. (1999). Cognitive styles and distance education. Online Journal of Distance Learning Administration, 2(3), 1-17.

Messick, S. (1995). Cognitive styles and learning. In W. Lorin (Ed.), International encyclopaedia of teaching and teacher education (2nd ed.). UK: Cambridge University Press.

Pooja. (2018). Effect of multimedia instruction on academic achievement in relation to cognitive styles and achievement motivation of 9th grade students in English. Chandigarh.

Rahmawat, L. (2018). The effect of CIRC strategy and achievement motivation toward students' reading comprehension. Jurnal Pendidikan dan Pembelajaran Bahasa Indonesia, 7(1), 25-37. Retrieved from https://ejournal-pasca.undiksha.ac.id/index.php/ jurnal_bahasa/article/view/2979

Sharma, H. L., \& Ranjan, P. (2018). Effect of cognitive styles and achievement motivation on academic achievement of 9th grade students through multimedia and traditional instructional strategies: An experimental study. International Journal of Management, IT $\mathcal{E}$ Engineering, 8(12).

Sujito, B. T., Budiharso, T., Solikhah, I., \& Mutaqin, W. M. (2020). The effect of analogy variations on academic writing: how Indonesian EFL students perform with different cognitive styles. Journal of Social Studies Education Research, 10(1), 116-132.

Witkin, H., Oltman, P., Raskin, E., \& Karp, S. (1971). Manual: Embedded figures test; children's embedded figures test; and group embedded figures test. Palo Alto, CA: Consulting Psychologists Press. Inc.

Yaman, H., Dundar, S., \& Ayvaz, U. (2017). Achievement motivation of primary mathematics education teacher candidates according to their cognitive styles and motivation styles. International Electronic Journal of Elementary Education, 7(2), 125-142. 